\title{
Just like Henry James (Except with Cannibalism): The International Weird in H. P. Lovecraft's 'The Rats in the Walls'
}

\author{
Dennis Wilson Wise, University of Arizona
}

\begin{abstract}
:
The early short story 'The Rats in the Walls' (1924) is recognized as the best of H. P. Lovecraft's fiction prior to 'The Call of Cthulhu', but this story is also non-cosmic and therefore (for some) not truly 'Lovecraftian'. In conjunction with dense prose and seemingly throwaway references, this view has made 'Rats' arguably the most inadequately read of Lovecraft's major works. This article proposes that we read 'Rats', Lovecraft's first tale within an unofficial 'witch cult' trilogy, as a story of the path not taken in modern weird fiction. Using Henry James's 'The Jolly Corner' (1908) as a companion piece, I argue that the international weird forms a major component of Lovecraft's text. Far from portraying horrors merely personal in scope, Lovecraft uses the Delapore family and their geographical dislocations between two distinct nation-states, America and England, to signal what he sees as the historical rise and fall - or evolution and de-evolution - of culture itself.
\end{abstract}

Keywords: Atavism; weird fiction; horror; Nyarlathotep; Catullus; globalgothic.

Commonly praised as H. P. Lovecraft's best early short story, 'The Rats in the Walls' (1924) remains something of an outlier, even an enigma, within his corpus. Non-cosmic yet gruesomely chilling, it has inspired readings that range from psychoanalytic and Marxist to even a Schopenhauerian 'pain of life' narrative. ${ }^{1}$ Still, the story also leaves critics at something of a loss. S. T. Joshi considers it 'a very difficult case', its narrator's moral responsibility ambiguous, and George $\mathrm{T}$. Wetzel attempts to integrate

Gothic Studies 23.1 (2021): 96-110

Edinburgh University Press

DOI: $10.3366 /$ gothic. 2021.0080

(C) Dennis Wilson Wise

www.euppublishing.com/gothic 
'Rats' (somewhat dubiously) into the Mythos by categorizing the whole Delapore family as 'ghoul-changelings'. ${ }^{2}$ More often, though, critics subsume 'Rats' into a larger narrative of Lovecraft's aesthetic development - his transition from micro- to macrocosm. For David E. Schultz, Lovecraft's early tales 'receive our attention primarily because they anticipate' later works like 'The Call of Cthulhu' in $1926{ }^{3}$ The primary value of 'Rats', in other words, lies as a stepping-stone to the cosmic horror. Still, this aesthetic position - often combined with mining the tale for biographical details on Lovecraft or his racial anxieties - also tends to discourage attentive close reading of the text. The secondary literature either skirts around or outright overlooks odd, perplexing, or seemingly inexplicable pieces of information; no one reading tries to orchestrate all the text's facts into a single coherent interpretation. The strangeness of 'Rats' itself, too, probably contributes to this lack. Beyond its simple density, the tale - as Robert $\mathrm{H}$. Waugh observes - has two different plotlines, both operating on different levels of reality: a realistic storyline about a cannibalistic family, and a fantastic storyline concerning the eponymous rats. ${ }^{4}$ Waugh attempts to resolve this tension by reading 'Rats' as a story about the First World War, but even this reading shortchanges the international weird - an element, I argue, that grants 'Rats' its remarkable character.

This international weird constitutes something like a middle path between nineteenth-century gothic fiction and Lovecraft's cosmic weird of the late 1920s and 1930s - a precursor, in fact, to the globalgothic, a recent term for how contemporary 'discourses of globalisation repeatedly turn to gothic tropes in articulating the social, culture and economic impacts of a new world order'. ${ }^{5}$ The model of the nation-state, however, still underpins Lovecraft's international weird; and, rather than globalization, it invokes early twentieth-century discourses of cultural evolution, scientific racism, and amateur anthropology. A useful companion to 'Rats', though, is Henry James's 'The Jolly Corner' (1908). In this story, a man returns to New York after several decades abroad in Europe. To his dismay, he encounters an American doppelgänger version of himself - a situation that deepens James's famed international theme through a supernatural element. Yet, although protagonist Spencer Brydon claims to have 'followed strange paths and worshipped strange gods' while in Europe, he merely refers to continental dissipation and hedonism ${ }^{6}$ - and Lovecraft, needless to say, prefers his strange gods and paths more literal. As such, rather than examining minute differences in national character or attitude, Lovecraft employs his international weird to recapitulate what he sees as the biological logic of growth, decline, and collapse on cultures and on peoples. Temporarily 
suppressing the gothic aspects of America's own history, Lovecraft makes the New World in 'Rats' symbolize progress and evolution, the Old World primitivism and regress, and Delapore's final descent into atavism, when it comes, far from being a personal horror only, actually echoes the alleged inevitability of cultural collapse. Old civilizations always die - they never just fade away. As such, rather than a mere stepping-stone to cosmic indifferentism, 'Rats' may be seen as the path not taken by modern horror - a direction weird fiction might have travelled had not Lovecraft and his heirs relished the later, greater dread of cosmic horror.

\section{Atavism and the International Weird}

Although most critics firmly situate Lovecraft as a weird writer, few would deny the weird's gothic origins, and 'Rats' is easily Lovecraft's most gothic tale. On one hand, S. T. Joshi defines weird fiction as a worldview rather than a genre, dismissing 'gothic fiction' as a vague term for 'anything written subsequent to Poe', ${ }^{7}$ Lovecraft himself had little sympathy for standard gothic machinery like 'secret murder, bloody bones, or a sheet form clanking chains according to rule. 8 Yet little of the weird worldview - that is, cosmic indifferentism - infiltrates 'Rats'. The tale also has plenty of secret murder, bloody bones, and gothic excess, including skeletons who can show (Lovecraft would have us believe) 'cannibalistic intent' and 'panic fear' after three centuries of decomposition. ${ }^{9}$ Often linked to Poe's 'The Fall of the House of Usher', too, the story makes several sly allusions to the gothic tradition: domestic pets sensing the spectral entity before the humans, or a character's 'hackneyed' exclamation of "My God!"' when a horror is first revealed (92, 105). Just as pointedly, 'Rats' contains four of the five gothic elements - everything except female heroines - noted by Jerrold E. Hogle in his introduction to The Cambridge Companion to the Modern Gothic: antiquated settings (Exham Priory), ghostly or monstrous figure (the rats), conflicting systems of belief that pull characters toward outmoded superstitions (Delapore and his family history), and over-the-top word patterns or images. ${ }^{10}$ Even more importantly, the Gothic - despite its intimations of anti-modernity - is 'deeply bound up with the contradictions basic to modern existence'. ${ }^{11}$ As I will show, Lovecraft uses 'Rats' to give shape and meaning to those contradictions in the immediate post-WWI era, and his narrator's 'transatlantic heritage' (91) offers a miniature parallel to a non-cosmic yet international macrocosm: the process of evolution and de-evolution seen by Lovecraft as dooming every civilization.

Lovecraft's immediate inspiration for 'Rats', though, most certainly did not come from gothic fiction, James's 'The Jolly Corner', or even 
Oscar Wilde's The Canterville Ghost (1887). Instead, Lovecraft drew his inspiration from Margaret Murray's quasi-anthropological The Witch-Cult in Western Europe (1921), a book arguing that ancient pagan practices survived the growth and emergence of Christianity, though soon forced underground by persecution, and they formed the real historical basis for such events as the Salem Witch Trials. ${ }^{12}$ Although historians at the time dismissed Murray's witch-cult thesis, what seemed to terrify Lovecraft on a personal level, as W. Scott Poole has shown, had less to do with a universe indifferent to human existence than does Lovecraft's visceral certainty, following Murray, that 'a long, secret tradition of the practice of witchcraft had endured through 2,000 years of Christianity' and survived into the twentieth century. ${ }^{13}$ In other words, beneath the veneer of contemporary civilization there lurks a dark underbelly of superstition and dread that, linked by Lovecraft to a racialized subhuman, threatens continually to return - and to destroy. Although Poole focuses on Lovecraft's later work, this witch-cult terror dominates the three early short stories written by Lovecraft in rapid succession during a creative dry spell otherwise lasting two years. In fact, 'Rats' (written August - September 1923), 'The Unnamable' (September 1923), and 'The Festival' (October 1923) all comprise something like an unofficial witch-cult trilogy. The latter two tales share nearly identical plots, including narrators institutionalized at St. Mary's mental hospital in Arkham, but their focus is regional rather than international. Their horrors stem from New England and New England's uniquely gothic past. In 'Rats', though, Lovecraft broadens his scope to encompass not only New England and old England but also, significantly, the American South. As a result, Lovecraft extends the possibility of atavism - including the threat of cultural regression-to trans-regional as well as transatlantic depths.

In what follows, I trace the international weird in 'Rats' through four major phases of historical and geographical movement. The first three phases follow a pattern of development, apogee, and decline. The final phase, which recounts the main events of the story, depicts a precipitous historical denouement. Although Lovecraft traces the rise, apex, and fall of the Delapore family, their familial history also mirrors the inevitable decline and fall (as Lovecraft saw matters) of great world cultures. Just as Murray's witch-cult thesis speaks directly on 'Rats', so too does Oswald Spengler's The Decline of the West. Spengler's work had appeared in English translation only in 1926 and 1928, so some years after Lovecraft wrote his story, but the 'idea of the decline of the West' had already long engaged Lovecraft's interests, even if prior to Spengler Lovecraft lacked any 'general framework in which to express the notion'. ${ }^{14}$ According to 
Spengler, cultures are organisms that follow a biological life cycle of birth, development, apogee, and decline. By working this analogy between the Delapore family and Spengler's theory of culture, two results emerge. First, the downfall of the Delapores begins neither with our narrator's relocation to England nor his restoration of Exham Priory, but with the American Civil War - the fall of the Old South idealized by Lovecraft himself. Second, the atavistic horrors that befall the tale's narrator include an international dimension qualitatively distinct from Lovecraft's later cosmic fiction or the regional horrors in 'The Unnamable' and 'The Festival'. At the same time, only this international reading orchestrates all the textual facts in 'Rats' into one consistent interpretation.

\section{Phase 1: Development in the Old World}

As shown by Figure 1, the first phase spans multiple millennia, and its origins belong to prehistory; wildly, Delapore guesses that they reach back 'ten thousand years' (105). Here, more so than the other phases, Lovecraft's dense prose and compression of backstory seems to have confounded the secondary literature. The major lacuna involves Nyarlathotep, a figure obviously critical to the Mythos. The de la Poers, we should remember, inherited their ancestral family cult, whose true founder appears to be none other than the mad faceless god himself. Certainly, the text informs us that fiend-born rats lead Delapore to the center of the earth where 'Nyarlathotep [...] howls blindly to the piping of two amorphous idiot flute-players' (107) - and yet, between two prominent champions of the Mythos's centrality to Lovecraft, Will Murray confesses himself mystified as to 'what purpose the brief evocation of Nyarlathotep' serves, and Robert M. Price dismisses the reference 'a mere cast-off mention and nothing more'. ${ }^{15}$ Unlike some other Lovecraftian narrators, though, Delapore has never read forbidden lore. He lacks any outside reference for how he comes to know Nyarlathotep's name. This suggests that some kind of deep psychic connection exists between them. If this inference seems thin, we also read Sir William Brinton stating unequivocally that the tunnel leading into Exham Priory had been chiseled from beneath (104), which implies that something - or someone - dark and powerful had done so. Indeed, although the secondary literature rarely cites the tunnel evidence, it adds further proof that Delapore's final ravings are not pure insanity, even had Thornton, the psychic investigator, not partially shared Delapore's intimations of the supernatural. Yet the presence of Nyarlathotep takes 'Rats' firmly beyond its gothic trappings and into the weird. It imbues Lovecraft's tale with the pale limits of modernity's scientism, an incipient aura of the cosmic fear that would later so strongly mark the Mythos. 


\begin{tabular}{|c|c|}
\hline & \multirow{3}{*}{$\begin{array}{l}\text { PHASE 1 } \\
\text { Old World (development) } \\
\text { - } \quad \text { ca. } 8000 \text { (?) B.C. - cult founded by Nyarlathotep. } \\
\text { - } 3000-2000 \text { BC: } \text { site of prehistoric temple; contemporary } \\
\text { with Stonehenge. Cannibalism; sacrifice; burnt offerings. } \\
\text { - } 55 \text { BC (at earliest): Rites of the old cult transferred to the } \\
\text { worship of Cybele (Magna Mater), which adds castration } \\
\text { practices and a eunuch priesthood. } \\
\text { - } \quad \text {-500 AD: Romans vainly forbid the cult to its citizens. } \\
\text { - } 500-1000 \text { AD: 'certain among the Saxons' added to site, } \\
\text { culminating in the old stone priory. } \\
\text { - } 1000 \text { AD: Powerful monastic order adds extensive } \\
\text { gardens; beginning of the subterranean breeding/eugenics } \\
\text { program for bipeds and quadrupeds as food. } \\
1261 \text { - Gilbert de la Poer, first Baron Exham, builds the } \\
\text { castle, and revitalizes the declining cult. } \\
1610 \text { (reign of James the First): Walter de la Poer, 11th } \\
\text { Baron Exham, murders family, flees to Virginia. } \\
\text { o Rats escape three months later (still 1610). } \\
\text { o Estates later given to the Norrys family. }\end{array}$} \\
\hline $\begin{array}{c}\text { PHASE 2 } \\
\text { New World (apogee) } \\
\text { - } 1610 \text { - Walter Delapore settles in Virginia } \\
\text { O Between 1848 and 1865 - Randolph } \\
\text { Delapore becomes a voodoo priest. } \\
\text { - } 1862 \text { or 1865 - Carfax burns and grandfather } \\
\text { Delapore dies in the fire. Letter also burns. }\end{array}$ & \\
\hline \multirow{2}{*}{$\begin{array}{l}\text { PHASE 3 } \\
\text { New World (decline) } \\
\text { - } \quad 1865-\text { Family moves to Massachusetts. } \\
\text { - } \quad 1904-\text { Father Delapore dies. } \\
\circ \quad \text { Alfred (b. 1894, d. 1921) } \\
\circ \quad \text { Narrator (b. 1855 or 1858) } \\
\text { - } \quad 1917 \text { - America enters WWI; Alfred Delapore } \\
\text { enlists in the air service. } \\
\text { - } \quad 1918 \text { - Narrator Delapore purchases Exham } \\
\text { Priory from the Norrys family; begins caring } \\
\text { for his invalid son. } \\
\text { 1921 - Alfred succumbs to wounds received in } \\
\text { the war. Narrator begins renovations on Exham } \\
\text { Priory. } \\
\text { 1923 (July 16 } \\
\text { the Atlantic Ocean, reversing the journey of } \\
\text { Walter de la Poer. }\end{array}$} & \\
\hline & $\begin{array}{l}\text { PHASE } 4 \\
\text { Old World Revisited (precipitous atavism) } \\
\left.\text { - } 1923 \text { (July } 16^{\text {th }}\right)- \text { narrator de la Poer returns to Exham } \\
\text { Priory. Reverts to old spelling of his name. } \\
\text { - July } 22^{\text {nd }}-\text { first spectral incident; only cats notice. } \\
\text { - July } 24^{\text {th }}-\text { de la Poer's first swineherd dream. } \\
\text { - July } 25^{\text {th }}-\text { sleeps in the sub-cellar with Norrys; } 2^{\text {nd }} \\
\text { swineherd dream; find the Atys inscription. } \\
\text { - July } 26^{\text {th }} \text {-August } 6^{\text {th }}-\text { de la Poer and Norrys go to London } \\
\text { to fetch specialists; no spectral incidents in the } \\
\text { meanwhile. } \\
\text { - August } 7^{\text {th }}-\text { return to Exham Priory; third swineherd } \\
\text { dream. }\end{array}$ \\
\hline & $\begin{array}{l}\text { August } 8^{\text {th }}-\text { descent into twilit grotto. Full atavism; } \\
\text { narrator returns to Nyarlathotep. }\end{array}$ \\
\hline
\end{tabular}

Figure 1. The Four Phases in Lovecraft's International Weird.

After Nyarlathotep's cult builds its first known temple during the Stonehenge era, we stand on surer historical footing. At this time, their rites probably 'only' include cannibalism, murder, burnt offerings, and other associated odds and ends. Around two millennia later, sometime during the reign of the Caesars, the first true developmental step forward arrives - a case of religious syncretism. The old Nyarlathotep cult merges with a Roman import from Phrygia, the worship of Cybele, the Magna Mater. New rites involving mass castration are introduced. So is a eunuch priesthood. Again, this is a logical extrapolation from the text. Although Lovecraft never mentions castration or a eunuch priesthood explicitly, the narrator finds an inscription to Atys in his sub-cellar, and he shivers because he knows 'something of the hideous rites of the Eastern god' from having read Catullus (100). In Catullus 63, Attis castrates himself in order to better serve the Goddess of Dindymum; his devoted comrades follow suit, unmanning their 'bodies in mighty hate of Venus'. ${ }^{16}$ This syncretism between the Nyarlathotep and Cybele cults, then, signals the 
first known evolution of the ancient religion - an evolutionary step all the more appalling, in Lovecraft's view, for refining destructive human instincts for savagery and primitivism.

Indeed, Rome's later inability to forbid Cybele worship to its citizens presages an overall theme in 'Rats': subversion from within. As much as Lovecraft admired classical Rome, even civilizations at their height cannot forever stave off those who seek a return to their basest natures. Yet a decline for Rome corresponds to an advance for the newly syncretized religious cult, and the next great leap forward happens around the first millennium. The cultists build an 'old stone priory' atop their old temple and construct an extensive series of gardens (92). As we later learn, these gardens feed the cult's subterranean herds of quasi-humans, and so we can date to 1000 A.D. the development of a new breeding program designed to provide the cultists a safe and reliable, yet well-hidden, diet of semi-human flesh. We might even consider this breeding program a medieval form of negative eugenics. Dr. Trask, an anthropologist, ascertains an evolutionary chain for the captive quadrupeds lasting 'through the last twenty or more generations' (106). Around this time, too, another instance of religious syncretism reaches completion. Given the dominance of Christianity at $1000 \mathrm{AD}$, only by outwardly adopting Christian practice can the powerful 'monastic' order (92) of Cybele-Nyarlathotep persevere undetected through the decades. Still, a steep decline begins following the Norman Conquest, and fresh vitality is only injected into the flagging cult by Gilbert de la Poer, first Baron Exham, in 1261. The de la Poers build a castle next to the old stone priory, perfect (presumably) the breeding program, and in fact grant the cult a veneer of aristocratic English respectability - another evolutionary adaptation that, once again, allows taboo practices to flourish undetected. Yet all comes to a crashing end in 1610 when Walter de le Poer, eleventh Baron Exham, discovers the family secret. He murders his kin, closes the Priory, and flees to Virginia. The lands are given over to the Norrys family. ${ }^{17}$

\section{Phase 2: The American South and the Great Leap Forward}

If phase 1 chronicles the Nyarlathotep cult as it slowly develops over forty centuries, phase 2 witnesses a major and sudden evolutionary change of direction. Although Gilbert and his descendants did not found their ancestral cult, it matured under their stewardship, safely surviving into the early modern period until Walter de la Poer's unforeseen dagger. Now known as Delapore, however, Walter's emigration to Virginia signals a decisive rejection of the Old World. He rejects Europe's history, the crushing weight of its ancient past, and he rejects all its old gods, all its 
old religions - those things that can be suppressed but never destroyed, not entirely. Yet when Walter crosses the Atlantic, he enters a New World. It is a land free from the burdens of history, a land innocent of half-forgotten memories and Paleolithic survivals. Nor has the significance of Walter's relocation to Virginia, rather than to Lovecraft's own New England, been properly appreciated. Despite its youth, Lovecraft knew that a state like Massachusetts was doomed to suffer Puritan repression and lurking hints of witchcraft - precisely the sort of primal degeneration that Walter Delapore feared about Exham Priory. The Virginian plantations along the banks of the James, though, offer a horizon infinitely brighter in comparison. Tellingly, Lovecraft had always idealized the Old South. He considered the capitol of Virginia, Richmond, a 'second home-town' as well as the 'cradle of American civilization'. ${ }^{18}$ Even as a schoolboy, he delighted in annoying his teacher, the daughter of a Union veteran, with compositions 'all flaming with love and glorification of the South! ${ }^{19}$ So when Walter Delapore settles there, he sets foot upon an allegedly Edenic land free of dark religions, Yankee commercialism, and-just as significantly for Lovecraft-abolitionist tendencies.

A golden age therefore dawns for the Delapores. Walter establishes himself as a gentleman farmer in the heartland of a slave-based agrarian economy. During this time, the only blight upon the family honor comes from Randolph Delapore, who 'went among the negroes and became a voodoo priest' (93), a situation that shows how a few will always voluntarily seek atavistic regression. Subversion from within - bolstered by illegitimate racial mixing, at least according to Lovecraft's problematic racialized logic of contamination - is the great danger all civilizations must face. Yet when the golden age ends, it does so through the American Civil War. The specific moment comes in either 1862 or 1865, the two times Federal troops threaten Richmond, which is being defended by our narrator's father, a Confederate soldier. Of these two dates, the latter is more tempting. If Carfax burns in 1865, then the decline of the Delapores coincides with Ulysses S. Grant capturing the Confederacy's capitol on 2 April. Exactly one week later, the Civil War ends when Robert E. Lee formally surrenders to Grant at Appomattox Courthouse.

And yet, if Carfax's destruction comes in 1865, Lovecraft is fudging his history. Although the narrator clearly blames the Yankees for incinerating Carfax, it was actually Confederate soldiers who, hoping to cover their retreat on Evacuation Sunday in 1865, started the blaze that spiraled out of control and soon enveloped half Richmond. Of course, Lovecraft might have deliberately played fast and loose with the known facts. When defending his use of Gaelic over Cymric in his narrator's final 
linguistic atavism, for example, Lovecraft jokingly states that, as 'with anthropology - details don't count'. ${ }^{20}$ Still, the father of our narrator might just as easily (and more heroically) have defended Richmond in late spring 1862 against General McClellan's failed Peninsula Campaign. Depending on Carfax's distance from the city proper, pillaging Yankees might have set Carfax ablaze despite their overall failure to capture the capitol. Robert H. Waugh, incidentally, chooses the 1865 date for Carfax's burning but forgets about this Peninsula Campaign. ${ }^{21}$ Either way, his article overlooks the symbolism of linking Carfax's burning with the end of the American South.

\section{Phase 3: Decline, Decadence, and Modernity}

Whether the Delapores' golden age ends in 1862 or 1865, the third phase in 'Rats' begins once the remaining family - father and son - relocate to Massachusetts. In contrast to carpet-bagging Yankees, Southerners rarely migrated north after the Civil War, but this unusual move helps Lovecraft signal a new shift in his tale's pre-history. The Delapore family has now entered a phase of decline. Indeed, throughout his career Lovecraft consistently links decline with cultural decadence; it applies to all races in their final stages, whether the Delapores, the star-headed Old Ones from At the Mountains of Madness (1936), or the Elder Things (the 'flying polyps') who destroyed the Yithians in 'The Shadow Out of Time' (1936). Even Lovecraft's idealized real-world Virginia was not immune from decline and unwanted cultural contamination. In 1929 he wrote that, although Virginia maintained old England's heritage better than New England, 'I fear it's doomed... Even now there's altogether too much blather about progress and money and industry in the South'.2 Financially, though, the Delapore family fortunes wax considerably. A few decades are all that are needed for the narrator to acquire enough wealth to purchase and renovate Exham Priory. Yet their cultural situation is more dire, at least from a Lovecraftian standpoint. The narrator becomes a 'stolid Yankee' ignorant of his forgotten family history, and he happily exchanges an aristocratic Virginian agrarianism - including, incidentally, its carefully maintained racial hierarchies - for 'the greyness of Massachusetts business life' (90). Despite this falling off in phase 3, however, the Delapores' decline is not yet irreversible - and Lovecraft injects a rare ray of hope in the person of young Alfred Delapore.

The few facts known about Alfred all speak highly in his favor. When the United States enters the Great War, an event Lovecraft had privately championed for years, Alfred Delapore volunteers immediately, thus joining the small cadre of noble WWI veterans sprinkled throughout Lovecraft's fiction. Even more significantly, Alfred is alone among 
Lovecraft's veterans to become an aviator. This profession, still in its infancy in 1917, was arguably the early twentieth century's most romantic innovation, and Lovecraft personally found the idea of flight incredibly exciting. ${ }^{23}$ Hence, although the Delapores are suffering from spiritual decline and decadence in phase 3, Alfred resuscitates Virginia's old noble spirit. He rides the wave of technological progress into the future. Just as the European de la Poers had ushered their family cult into the early modern period, the American Delapores have, thanks to Alfred, the opportunity to enter late modernity with eyes wide open. Yet that all comes to a close when war-related injuries bring Alfred's life to an end in 1921.

Strangely enough, the thematic impact of Alfred's death is something else unaccountably overlooked by the secondary literature. If Alfred represents the chance for his family to move seamlessly into modernity, then Lovecraft achieves a deft symbolism by associating Alfred's death with the same war that deeply damaged Western civilization's faith in social and cultural progress. In post-war Europe, a wide-spread pessimism soon came to overturn the old Enlightenment optimism. Many of the modernist art movements despised as decadent by Lovecraft - literary modernism, cubism, Dadaism, surrealism - arose partly to reflect this cultural despair. Progress thus ends for the Delapores at the same time it seemingly ends for all Europe. As such, 'Rats' can be viewed as weird fiction's response to a cultural situation that avant-garde works such as T. S. Eliot's The Waste Land (1922), which Lovecraft had read - and mocked - just a few months earlier, failed to address to Lovecraft's satisfaction. At the same time, biological progress ends for the Delapores just as abruptly as spiritual and cultural progress. The family line ends with Alfred's death; the Delapore genes have been condemned to extinction. Even had the narrator been married in 1921, he will have no more children, being either 63 or 66 years old. Phase 3 culminates, not in flames as at Carfax, but in sad infertility. The narrative logic is clear. If biological progress forward has been blocked, where else can the family go but backward? Evolution must become de-evolution. Even before renovating his newly acquired estates at Exham Priory, the narrator has no hope of fulfilling his unconscious biological imperative. Hence the inexorable Lovecraftian logic of decline, regression, and extinction will drive the narrator like a lemming to his fate.

\section{Phase 4: Atavism - and Return}

This final phase comprises nearly all the real-time events in 'Rats', and they chronicle the precipitous, yet historically inevitable, collapse of the Delapores. Blithely unaware that the modern conveniences built into 
Exham Priory cannot erase the past, our narrator orders up the restoration of his ancestral home. On 16 July 1923, he reverses the journey of his ancestor Walter across the Atlantic Ocean, and he forsakes the promises of the New World for a history-riddled island with gothic depths unimaginable to the bourgeois individual he has become. ${ }^{24}$ As a final heedless gesture of his doom, Delapore even reverts to the former spelling of his surname: 'de la Poer'. The end, when it comes, comes quickly. Six days after returning to Exham Priory, the first spectral incident occurs, sensed only by nine cats; two days later, on 24 July, narrator de la Poer has the first of three prophetic swineherd dreams, which offers another ominous foreshadowing of the inevitable. In this dream, a 'mighty swarm of rats rained down on the stinking abyss and fell to devouring beasts and [swineherd] alike' (98). Since we eventually learn that the swineherd is de la Poer himself, we can realize how some dark entity - probably Nyarlathotep, original founder of the ancient cult - desires to reabsorb a de la Poer back into the fanatical fold. Quite literally, daemonic rats psychically herd the herder of swine back to Nyarlathotep's bosom. Destiny has been set. True horror arises from the inexorable intertwinement of personal destruction with cultural decline.

Phase 4, however, still has a few surprises for poor de la Poer. On 25 July he descends into a sub-cellar with Captain Norrys and sees the 'ATYS' inscription, which he recognizes (as mentioned) from having read Catullus 63. Once again, the secondary literature makes astonishingly little of this gem. Critics typically see the castration rites referenced by the poem as nothing more than extra shock-value gruesomeness, a device typical of early Lovecraft. Even the two most highly regarded psychoanalytic readings of 'Rats' - one by Lévy and another by St. Armand - make little of this reference, although arguably their Jungian framework is less interested in castration themes than a Freudian framework would be. Basically, however, the narrator de la Poer is already a castrated Attis-figure. Though not literally a eunuch, his age and his lack of living offspring have effectively made him so. Even more importantly, commentators have missed how the religious fanaticism that haunts Catullus 63 relates directly to the last living priest of the Cybele-Nyarlathotep cult. Why, after all, does de la Poer 'shiver' (100) when he sees the ATYS inscription? The hideous nature of castration rites is one obvious reason, of course, but Catullus 63 goes far beyond that lone act. In the poem, Attis quickly comes to regret that hasty decision - but Catullus shows, too, how the goddess Cybele, having once snared her prey, refuses to let that prey go.

In the poem, when Attis laments his folly and cries out in homesickness for his native land, Cybele orders a lion to fetch the hapless Attis back, 
who spends the rest of 'her' life (Catullus plays the pronoun game) as handmaid to the jealous Goddess of Dindymum. The poem ends with the speaker's following fearful prayer:

Goddess so great, goddess Cybele, lady goddess of Dindymum,

May all your madness stay far from my home, mistress:

Drive others in frantic speed, drive others to madness. ${ }^{25}$ (emphasis added)

So great is Cybele's power, then, that the speaker knows he can never resist the Goddess's attentions - he can only hope Her madness befalls someone else. In a sense, the Goddess answers the speaker's prayer. She chooses de la Poer instead. Accordingly, although our narrator might consciously shiver because of the gruesome and hideous rites of the Eastern God', an even deeper terror actually afflicts him. He fears the loss of his reason, his loss of independent personal identity. He fears the religious madness lurking in the soul's heart despite modern civilization, despite the Enlightenment, despite the materialism and the greyness of New England business life. In a sense, our narrator is an actor playing the role of Martin Dysart from Peter Schaffer's 1973 play Equus, where the rationalistic Dysart, a psychologist who loves classical antiquity, finds himself increasingly disturbed by the daimonic religious ecstasy that absorbs his teenage working-class client. When de la Poer shivers, he does so because he intuits, on some deep level, the ancestral Dionysian doom binding him with invisible shackles. He never has the chance to utter the fearful prayer pronounced by the speaker in Catullus 63; he has no opportunity to forestall his terrible fate by wishing it upon someone else.

The conclusion to phase 4 is well-known to all Lovecraft enthusiasts. When de la Poer makes his final descent into the twilit grotto, he succumbs to cannibalism and full spiritual atavism in less than 24 hours. In this atavism we see, as strongly as anywhere else, the gothic inheritance of Lovecraft's international weird. If the gothic is 'really about the profoundly conflicted core of modernity itself, ${ }^{26}$ then de la Poer, once he embraces his fate, also consciously rejects the modern world that, due to his son's death, his family can now never enter. Modernity had brought his family nothing but grief - once through the Civil War in the nineteenth century, then again through the First World War in the twentieth. Both these familial catastrophes are yoked together by de la Poer in his final madness: 'The war ate my boy, damn them all ... and the Yanks ate Carfax with flames and burnt Grandsire Delapore and the secret' (108). Yet Lovecraft's own cultural views add a biological dimension that roots the horror in 'Rats' in something greater than gothic fiction's traditional concern with the reversal of progressive 
time. When Lovecraft's decenters the locus of horror from any one geographic location or nationality, the international weird broadens the scope of horror to encompass the historical and cultural trajectories of two different English-speaking - and predominantly Caucasian - nation-states. Combined with the unknown depths intimated by mad faceless Nyarlathotep, the earliest figure in Lovecraft's Mythos and a counter to the surety of modern scientism, 'Rats' introduces weird fiction to quasi-scientific notions of evolutionary progress and regression on a world stage.

These four phasal movements in 'Rats', then, represent the sum total of Lovecraft's international weird. From Old World to New - and then from New World back to Old - the Delapore family fortunes follow a logic of progress and regress, rise and fall. This is not cosmic fiction; still, Lovecraft's international weird showcases a thematic ambition unseen in James's 'The Jolly Corner'. Lovecraft, unfortunately, never followed up this line of aesthetic development; the other stories in his unofficial witch-cult trilogy limit themselves to New England. Still, it seems safe to say that Lovecraft's achievement in 'Rats' goes well beyond simply establishing a more convincing realism by integrating 'real history with the imagined genealogical history of the characters'. ${ }^{27}$ Nor is de la Poer's return to Exham Priory merely an American 'sign of affectation' where a nouveau riche pretends to European high culture. ${ }^{28}$ Something of the sort certainly marks the ending of 'Celephaiis' in which the body of Kuranes, the dreamer, washes up on shore by 'ivy-covered Trevor Towers, where a notably fat and especially offensive millionaire brewer enjoys the purchased atmosphere of extinct nobility' (30). Yet the tragedy of the narrator in 'Rats' culminates a 10,000-year-long epoch initiated by Nyarlathotep. It follows a cultural as well as familial cycle of growth, apogee, and decline, and it is concluded by a final, precipitous, atavistic fall.

In the end, Lovecraft creates through 'Rats' a new international or global weird orthogonal to his later cosmic weird. If critics have missed this international dimension to the story, part of the reason surely stems (as I have suggested) from limiting 'Rats' to only a stepping-stone in the Lovecraftian aesthetic, his transition from micro- to macrocosm. This has created several critical lacunae: the failure of anyone to suspect Nyarlathotep of founding the ancient cult later syncretized into Cybele worship; the thematic import of Alfred's death; or even how the terror of religious fanaticism informing Catullus 63 haunts the narrator, last living priest of his familial cult. Taken as a whole, though, 'Rats' offers readers a strange hybrid between the gothic and the weird. It employs several gothic tropes while ever-so-faintly satirizing them, and its weirdness suggests the 
parochial limitations of Delapore's confident bourgeois rationality, his unreflective faith in scientific exploration as he plumbs the depths of Exham Priory. In the process, the story can be viewed as precursor to the globalgothic - a tale that, by using the internationalism of the early twentieth century as its model, plays two distinct national histories (the United States and England) against one another. Of course, Lovecraft's views on the rise, apogee, and decline of cultures have now fallen widely out of favor, and his acceptance of Margaret Murray's witch-cult thesis - not to mention his virulent racism - were questionable even during the 1920s. Still, if my claims about the international weird ring true, 'The Rats in the Walls' - already acknowledged as Lovecraft's best early short story - might well be considered on par with his best cosmic fiction: a sadly abandoned, yet remarkable, direction in the development of the twentieth-century weird.

\section{Notes}

1. For the Marxist or Frankfurt School reading, see William F. Touponce, Lord Dunsany, H.P. Lovecraft, and Ray Bradbury: Spectral Journeys (Lanham, MD: Scarecrow Press, 2013), p. 103. For the Schopenhaurian 'pain of life' narrative, see Paul Montelone, "'The Rats in the Walls": A Study in Pessimism', Lovecraft Studies 32 (1995), 18-26, p. 18. Overall, though, the most influential readings of 'Rats' have been symbolic and psychoanalytic. The best two studies belong to Maurice Lévy, Lovecraft: A Study in the Fantastic, trans. by S. T. Joshi (Detroit: Wayne State University Press, 1988), and Barton Levi St. Armand, The Roots of Horror in the Fiction of H. P. Lovecraft (Elizabethtown, NY: Dragon Press, 1977). See also Michael T. Saler, As If: Modern Enchantment and the Literary Prehistory of Virtual Reality (Oxford: Oxford University Press, 2012), p. 149.

2. S. T. Joshi, H. P. Lovecraft: The Decline of the West (Mercer Island, WA: Starmont, 1990), p. 110; George T. Wetzel, 'The Cthulhu Mythos: A Study', in S. T. Joshi (ed.), H. P. Lovecraft: Four Decades of Criticism (Athens: Ohio University Press, 1980), pp. $79-96$ (p. 86).

3. David E. Schultz, 'From Microcosm to Macrocosm: The Growth of Lovecraft's Cosmic Vision', in David E. Schultz and S. T. Joshi (eds.), An Epicure in the Terrible: A Centennial Anthology of Essays in Honor of H. P. Lovecraft (Cranbury, NJ: Fairleigh Dickinson University Press, 1991), pp. 199-219 (p. 200).

4. Robert H. Waugh, "The Rats in the Walls", the Rats in the Trenches', Lovecraft Annual 2 (2008), 149-64 (p. 149).

5. Glennis Byron, 'Introduction', in Glennis Byron (ed.), Globalgothic (Manchester: Manchester University Press, 2015), pp. 1-10 (pp. 2-3).

6. Henry James, The Turn of the Screw, The Aspern Papers, and Two Stories, ed. by David L. Sweet (New York: Barnes \& Noble Classics, 2003), p. 275.

7. S. T. Joshi, The Weird Tale (Holicong, PA: Wildside Press, 1990), pp. 2-3.

8. H. P. Lovecraft, The Annotated Supernatural Horror in Literature, ed. by S. T. Joshi, revised edition (New York: Hippocampus Press, 2012), p. 25.

9. H. P. Lovecraft, The Call of Cthulhu and Other Weird Stories, ed. by S. T. Joshi (New York: Penguin, 1999), pp. 104-5. All subsequent quotations are from this edition. Page numbers will follow in brackets in the text. 
10. Jerrold E. Hogle, 'Introduction: Modernity and the Proliferation of the Gothic', in Jerrold E. Hogle (ed.), The Cambridge Companion to the Modern Gothic (Cambridge: Cambridge University Press, 2014), pp. 3-19 (pp. 4-5).

11. Hogle, 'Introduction', p. 6.

12. Margaret Alice Murray, The Witch-Cult in Western Europe: A Study in Anthropology. (Oxford: Clarendon Press, 1921).

13. W. Scott Poole, 'Lovecraft, Witch Cults, and Philosophers', in Carl H. Sederholm and Jeffrey Andrew Weinstock (eds.), The Age of Lovecraft (Minneapolis: University of Minnesota Press, 2016), pp. 215-30 (p. 217).

14. Joshi, Decline, p. 135

15. Will Murray, 'The Mask of Nyarlathotep', Lovecraft Studies 25 (1991), 25-29, p. 27; Robert M. Price, 'Debatable and Disturbing: Editorial Shards', Crypt of Cthulhu 72.9 (\#5) (1990), 2 (p. 2).

16. Catullus, 'Catullus 63: Text and Translation', trans. by S. J. Harrison, Mnemosyne, 57 (2004), 514-19, line 17, doi: www.jstor.org/stable/4433592.

17. Robert $\mathrm{H}$. Waugh makes an excellent inductive observation that the Norrys family was most likely loyalist during the English Civil War, its fortunes rising with that of Parliament and of Cromwell. Waugh, "The Rats", p. 162.

18. H. P. Lovecraft, Selected Letters II (1925-1929), ed. by August Derleth and Donald Wandrei (Sauk City: Arkham, 1968), p. 333.

19. S. T. Joshi and David E. Schultz, Lord of a Visible World: An Autobiography in Letters (Athens: Ohio UP, 2000), p. 28.

20. Lovecraft, Selected Letters I, p. 258.

21. Waugh, "The Rats", p. 157.

22. H. P. Lovecraft, Selected Letters III (1929-1931), ed. by August Derleth and Donald Wandrei (Sauk City: Arkham, 1972), p. 57.

23. Lovecraft, Selected Letters I, p. 240; Lovecraft, Selected Letters III, p. 57.

24. See Kenneth W. Faig Jr., 'The Parents of Howard Phillips Lovecraft', in David E. Schultz and S. T. Joshi (eds.), An Epicure in the Terrible: A Centennial Anthology of Essays in Honor of H. P. Lovecraft (Cranbury, NJ: Fairleigh Dickinson UP, 1991), pp. 45-77 (p. 56). Faig links the number of major mid-July events in Lovecraft's fiction to the death of his father Winfield Lovecraft during that month. 16 July is also when Robert Olmstead flees Innsmouth in 'The Shadow over Innsmouth', and the day Henry James formally became a British citizen.

25. Catullus, 'Catullus 63', lines 91-93.

26. Hogle, 'Introduction', p. 7.

27. Stefan Dziemianowicz, 'Outsiders and Aliens: The Uses of Isolation in Lovecraft's Fiction', in David E. Schultz and S. T. Joshi (eds.), An Epicure in the Terrible: A Centennial Anthology of Essays in Honor of H. P. Lovecraft (Cranbury, NJ: Fairleigh Dickinson University Press, 1991), pp. 159-87 (p. 172).

28. Joshi, Decline, p. 102. 


\section{Your short guide to the EUP Journals Blog http://euppublishingblog.com/}

A forum for discussions relating to Edinburgh University Press Journals

\section{The primary goal of the EUP Journals Blog}

To aid discovery of authors, articles, research, multimedia and reviews published in Journals, and as a consequence contribute to increasing traffic, usage and citations of journal content.

\section{Audience}

Blog posts are written for an educated, popular and academic audience within EUP Journals' publishing fields.

\section{Content criteria - your ideas for posts}

We prioritize posts that will feature highly in search rankings, that are shareable and that will drive readers to your article on the EUP site.

\section{Word count, style, and formatting}

- Flexible length, however typical posts range 70-600 words.

- Related images and media files are encouraged.

- No heavy restrictions to the style or format of the post, but it should best reflect the content and topic discussed.

\section{Linking policy}

- $\quad$ Links to external blogs and websites that are related to the author, subject matter and to EUP publishing fields are encouraged, e.g.to related blog posts

\section{Submit your post}

Submit to ruth.allison@eup.ed.ac.uk

If you'd like to be a regular contributor, then we can set you up as an author so you can create, edit, publish, and delete your own posts, as well as upload files and images.

\section{Republishing/repurposing}

Posts may be re-used and re-purposed on other websites and blogs, but a minimum 2 week waiting period is suggested, and an acknowledgement and link to the original post on the EUP blog is requested.

\section{Items to accompany post}

- A short biography (ideally 25 words or less, but up to 40 words)

- A photo/headshot image of the author(s) if possible.

- Any relevant, thematic images or accompanying media (podcasts, video, graphics and photographs), provided copyright and permission to republish has been obtained.

- Files should be high resolution and a maximum of $1 \mathrm{~GB}$

- Permitted file types: jpg, jpeg, png, gif, pdf, doc, ppt, odt, pptx, docx, pps, ppsx, xls, xlsx, key, mp3, m4a, wav, ogg, zip, ogv, mp4, m4v, mov, wmv, avi, mpg, 3gp, $3 g 2$. 